\title{
Dampak Korona pada SUTET 500 kV Terhadap Radio Interference
}

\author{
${ }^{1,2}$ Sekolah Tinggi Teknik PLN \\ ${ }^{1}$ christinewidyastuti@gmail.com
}

Christine Widyastuti'; I Nyoman Bagus Yudha Dharma ${ }^{2}$

\begin{abstract}
Corona can occur in SUTET because SUTET carries a high enough electric current and voltage, this causes excessive electrical pressure that is not proportional to the breakdown strength of the air around the conductor so that there will be a phenomenon where the electric field will collide with free electrons in the air and will form ionisations in the form of new ions and electrons. This process will continue as long as there are currents and voltages on the extra-high voltage network. This certainly will affect the surrounding environment through which SUTET is included, among others, interference with radio waves (Radio Interference). The addition of the number of subconductors is considered more effective in reducing corona losses and radio interference in each wicket than increasing the distance of the conductor to the ground. The impact of corona on a $500 \mathrm{kV}$ double channel SUTET on radio interference in the Greater Jakarta area is still within reasonable limits because it is still below the IEEE standard of $40 \mathrm{~dB}$.
\end{abstract}

Keywords: Corona, SUTET 500 kV, Radio Interference

\begin{abstract}
ABSTRAK
Korona dapat terjadi pada SUTET karena pada SUTET membawa arus dan tegangan listrik yang cukup tinggi, hal ini menyebabkan timbulnya tekanan listrik berlebihan yang tak sebanding dengan breakdown strength dari udara di sekitar konduktor sehingga akan terjadi fenomena dimana medan listrik akan bertabrakan dengan elektron bebas di udara dan akan membentuk ionisasi berupa ionion dan elektron baru. Proses ini akan berjalan terus selama ada arus dan tegangan pada jaringan tegangan ekstra tinggi. Hal ini tentunya akan mempengaruhi lingkungan sekitar yang dilalui oleh SUTET tersebut yang diantaranya ialah gangguan terhadap gelombang radio (Radio Interference). Penambahan jumlah subkonduktor dinilai lebih efektif untuk mengurangi rugi-rugi korona maupun radio interference pada tiap gawang dibandingkan peninggian jarak konduktor terhadap tanah. Dampak korona pada SUTET $500 \mathrm{kV}$ saluran ganda terhadap radio interference di daerah Jabodetabek masih dalam ambang batas wajar karena masih dibawah standard IEEE yaitu $40 \mathrm{~dB}$.
\end{abstract}

Kata kunci: Korona, SUTET 500 kV, Radio Interference 


\section{PENDAHULUAN}

Pembangunan ekonomi yang tumbuh dengan cepat menuntut PT PLN persero untuk menyediakan tenaga listrik dalam berbagai kebutuhan, untuk menunjang kebutuhan listrik tersebut maka dibuatlah Saluran Udara Tegangan Ekstra Tinggi (SUTET). Dalam prakteknya pembangunan SUTET ini secara tidak langsung juga membawa dampak pada lingkungan sekitarnya, dampak yang dimaksud disini ialah dampak negatif yang ditimbulkan oleh jaringan SUTET itu sendiri. Penggunaan arus dan tegangan yang cukup tinggi pada SUTET akan menimbulkan suatu fenomena yang disebut korona, korona pada SUTET ini seringkali menyebabkan bunyi desis di sekitar konduktor transmisi dan gangguan gelombang radio di sekitarnya.

\subsection{SUTET $500 \mathrm{KV}$}

Secara teknik, klasifikasi yang umum dari tegangan tinggi adalah sebagai berikut:

a. Tegangan tinggi (High Voltage), meliputi tegangan system: $20 \mathrm{kV}, 30 \mathrm{kV}, 70 \mathrm{kV}$, dan 150 $\mathrm{kV}$.

b. Tegangan ekstra tinggi (Ekstra High Voltage), meliputi tegangan system: $235 \mathrm{kV}$, dan 500 $\mathrm{kV}$.

c. Tegangan ultra tinggi (Ultra High Voltage), meliputi tegangan system $750 \mathrm{kV}$ ke atas.

Bila dua kawat sejajar yang penampangnya kecil dibandingkan dengan jarak antar kawat tersebut diberi tegangan, maka akan terjadi korona. Pada tegangan yang cukup rendah tak terlihat apa-apa, bila tegangan dinaikan maka akan terjadi korona secara bertahap. Korona pada sistem transmisi tenaga listrik biasanya dapat terlihat dengan jelas pada system transmisi yang mempunyai intensitas listrik yang cukup tinggi (tegangan yang besar) di Indonesia biasa disebut dengan SUTET (Saluran Udara Tegangan Ekstra Tinggi) dengan tegangan nominal system $235 \mathrm{kV}$ sampai $500 \mathrm{kV}$.

Pada keadaan udara kering dengan suhu dan tekanan atmosfir normal $\left(25^{\circ} \mathrm{C}\right.$ dan $\left.76 \mathrm{cmHg}\right)$, ketahanan breakdown udara ialah $29,8 \mathrm{KV} / \mathrm{cm}$ pada harga maksimum atau $21,1 \mathrm{KV} / \mathrm{cm}$ pada harga efektif. Perlu diketahui bahwa intensitas medan elektrostatik di sekitar konduktor tidak uniform, oleh karena itu kekuatan maksimumnya ada pada permukaan konduktor dan berkurang berbanding terbalik dengan pertambahan jarak dari pusat konduktor.

\subsection{Korona}

Elektron yang membawa arus listrik pada jaringan interkoneksi dan jaringan transmisi, menyebabkan timbulnya tekanan listrik berlebihan yang tak sebanding dengan breakdown strength dari udara di sekitar konduktor sehingga akan terjadi suatu fenomena dimana medan listrik akan bertabrakan dengan elektron bebas di udara dan akan membentuk ionisasi berupa ion-ion dan elektron baru. Proses ini berjalan terus selama ada arus dan tegangan pada jaringan tegangan ekstra tinggi ,akibatnya ion dan elektron menjadi berlipat ganda, terlebih lagi bila gradien tegangannya cukup tinggi. Berlipat gandanya ion dan elektron ini menimbulkan korona yang dapat terlihat berupa percikan busur cahaya yang seringkali disertai pula dengan suara mendesis dan bau khusus yang disebut dengan bau ozone. Sedangkan gangguan gelombang radio yang disebabkan oleh SUTET dapat ditimbulkan oleh wide band frekuensi dari beberapa sumber sebagai berikut:

a. Peristiwa korona discharge (pelepasan muatan listrik) di udara pada permukaan konduktor dan alat kelengkapannya.

b. Discharge (pelepasan muatan listrik) dan bunga api pada di titik stress tegangan pada isolator.

c. Bunga api (sparking) pada sambungan yang longgar atau tak sempurna.

Sifat dari korona adalah: 


\section{a. Sifat Korona Positif}

Korona positif berbentuk sebuah plasma seragam di sepanjang sebuah konduktor. Korona positif sering terlihat dengan pijaran berwarna biru/putih, meski sebagian besar emisi berada dalam ultraviolet.

\section{b. Sifat Korona Negatif}

Korona negatif dihadirkan dalam korona tak uniform, yang bervariasi sesuai dengan ciri permukaan dan ketidak teraturannya konduktor melengkung. Korona negative sering muncul sebagai gumpalan korona di tepi tajam, jumlah gumpalan berubah sesuai dengan kekuatan medan. Terbentuknya korona negative merupakan hasil dari sumber electron longsoran sekunder.

\section{METODE/PERANCANGAN PENELITIAN}

\subsection{Radio Interference (RI) Pada SUTET 500 KV}

Gelombang radio adalah satu bentuk dari radiasi elektromagnetik, dan terbentuk ketika objek bermuatan listrik dari gelombang osilator (gelombang pembawa) dimodulasi dengan gelombang audio (ditumpangkan frekuensinya) pada frekuensi yang terdapat dalam Frekuensi gelombang radio pada suatu spektrum elektromagnetik, dan radiasi elektromagnetiknya bergerak dengan cara osilasi elektrik maupun magnetic.

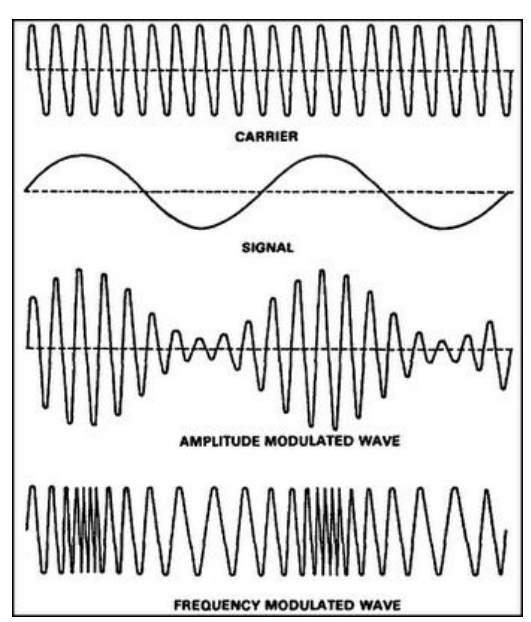

Gambar 1. Bentuk Gelombang dari AM Dan FM

Medan listrik yang ditimbulkan oleh SUTET $500 \mathrm{kV}$ mengakibatkan fenomena korona yang secara tak langsung mengakibatkan terjadinya proses pelepasan muatan listrik keudara. Proses pelepasan pada korona menghasilkan pulsa-pulsa arus dan tegangan pada konduktor saluran yang akhirnya dapat mengakibatkan gangguan pada gelombang radio.

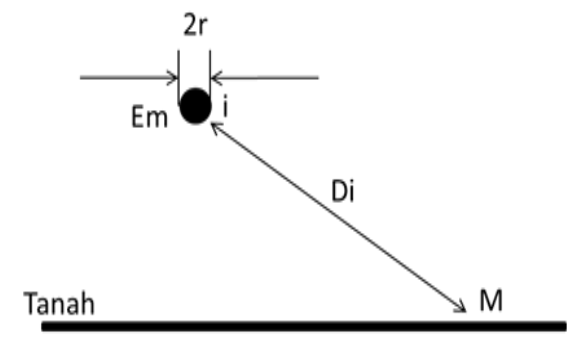

Gambar 2. Pengukuran Jarak Lateral Objek Untuk Menentukan RI. 
Penggunaan rumus empiris CIGRE dapat digunakan untuk menentukan besarnya RI pada tiap fasa dari konduktor SUTET $500 \mathrm{kV}$ pada saluran tunggal. Penggunaan rumus ini akan mempunyai beberapa factor penting yang dapat mempengaruhinya, yaitu:

- Jari dari konduktor $r$, atau diameter dari konduktor $d=2 r$

- Gradient potensial maksimum pada konduktor

- Jarak lateral objek yang akan dievaluasi radio interference nya dari kawat konduktor

- Faktor lain seperti frekuensi pengukuran dan keadaan cuaca

$$
\mathrm{RI}_{\mathrm{i}}=3,5 \mathrm{Em}+12 \mathrm{r}-33 \log _{10}\left(\frac{\mathrm{D}_{\mathrm{i}}}{20}\right)-30[\mathrm{~dB}]
$$

Langkah awal dalam perhitungan gradient potensial ialah dengan menghitung jari-jari equivalen dari konduktor.

$$
\begin{aligned}
& \mathrm{r}_{\mathrm{eq}}=\mathrm{R}(\mathrm{N} \cdot \mathrm{r} / \mathrm{R})^{\frac{1}{\mathrm{~N}}} \quad[\mathrm{~m}] \\
& E_{m}=\frac{1+\frac{(N-1) r}{R}}{N \cdot r \cdot \ln \left(\frac{2 H}{r_{e q}} \frac{1}{\sqrt{1+\left(\frac{2 H}{P}\right)^{2}}}\right)} \times \frac{V}{\sqrt{3}} \quad[\mathrm{kV} \mathrm{rms} / \mathrm{cm}]
\end{aligned}
$$

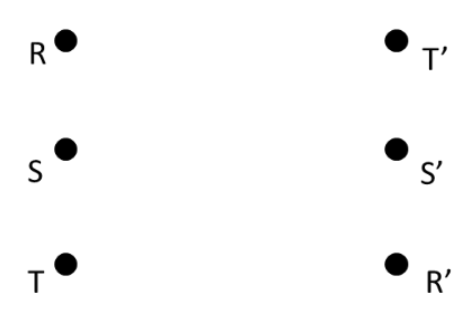

Gambar 3. Konfigurasi Konduktor Pada SUTET Yang Diamati

Akan didapat enam buah nilai RI yang terlebih dahulu dikonversikan kedalam satuan $\mu \mathrm{V} / \mathrm{m}$ dengan menggunakan persamaan berikut :

$$
\begin{aligned}
& \left.\left.R I_{(\mu v / m}\right)=10^{\left(R_{d B /} I 0\right.}\right) \\
& R I_{i}=\sqrt{R I_{i}^{2}+R I_{i}^{\prime 2}} \\
& 20 \log _{10}(R I \mu v / m)=R I_{d B}
\end{aligned}
$$

Pada perhitungan diatas nantinya akan diperoleh tiga nilai RI saja, sehingga dapat ditentukan nilai RI dari saluran dengan memilih dua nilai RI yang terbesar, atau jika didapatkan sebuah nilai RI yang lebih tinggi $3 \mathrm{~dB}$ dari yang lainnya maka nilai tersebut dapat dikatakan sebagai nilai RI dari saluran, jika pengukuran dilakukan pada frekuensi $1 \mathrm{MHz}$ maka level dari RI akan $6 \mathrm{~dB}$ lebih rendah, dan untuk mengetahui besar level dari RI pada keadaan hujan maka nilai dari RI salurannya ditambah $17 \mathrm{~dB}$.

$$
\begin{aligned}
& \mathrm{RI}_{\mathrm{t}}=\frac{1}{2} \text { (penjumlahan dua level RI yang terbesar) }+1,5 \\
& \boldsymbol{P}_{\boldsymbol{c}}=\mathbf{5 , 1 6} \times \mathbf{1 0}^{-\mathbf{3}} \boldsymbol{f} \sqrt{\boldsymbol{r} / \mathbf{2} \boldsymbol{H}} \boldsymbol{V}^{\mathbf{2}}\left(\mathbf{1}-\boldsymbol{V}_{\boldsymbol{d}} / \boldsymbol{V}\right)^{2}\left[\frac{\boldsymbol{k W}}{\boldsymbol{k m} / \boldsymbol{f a s a}}\right] \\
& \mathrm{T}_{\mathrm{PC}, \mathrm{RW}}=\mathrm{T}_{\mathrm{PC}, \mathrm{FW}}+0,3606 \mathrm{~K} \cdot \mathrm{V} \cdot \mathrm{r}^{2} \cdot \ln (1+10 \rho) \cdot \sum_{1}^{3 \mathrm{~N}} \mathrm{E}^{5}\left[\frac{\mathrm{Kw}}{\mathrm{Km} / 3 \mathrm{fasa}}\right]
\end{aligned}
$$


Tabel 1. Tabel Frekuensi dan Panjang Gelombangnya

\begin{tabular}{|c|c|c|c|c|}
\hline Nama band & Singkatan & $\begin{array}{c}\text { Band } \\
\text { ITU }\end{array}$ & Frekuensi & $\begin{array}{c}\text { Panjang } \\
\text { gelombang }\end{array}$ \\
\hline & & & $<3 \mathrm{~Hz}$ & $>100.000 \mathrm{~km}$ \\
\hline $\begin{array}{l}\text { Extremely low } \\
\text { frequency }\end{array}$ & ELF & 1 & $3-30 \mathrm{~Hz}$ & $\begin{array}{l}100.000 \mathrm{~km}- \\
10.000 \mathrm{~km}\end{array}$ \\
\hline Super low frequency & SLF & 2 & $30-300 \mathrm{~Hz}$ & $\begin{array}{c}10.000 \mathrm{~km}- \\
1000 \mathrm{~km}\end{array}$ \\
\hline Ultra low frequency & ULF & 3 & $300-3000 \mathrm{~Hz}$ & $\begin{array}{c}1000 \mathrm{~km}-100 \\
\mathrm{~km}\end{array}$ \\
\hline Very low frequency & VLF & 4 & $3-30 \mathrm{KHz}$ & $100 \mathrm{~km}-10 \mathrm{~km}$ \\
\hline Low frequency & $\mathrm{LF}$ & 5 & $30-300 \mathrm{KHz}$ & $10 \mathrm{~km}-1 \mathrm{~km}$ \\
\hline Medium frequency & MF & 6 & $\begin{array}{c}300-3000 \\
\mathrm{KHz}\end{array}$ & $1 \mathrm{~km}-100 \mathrm{~m}$ \\
\hline High frequency & $\mathrm{HF}$ & 7 & $3-30 \mathrm{MHz}$ & $100 m-10 m$ \\
\hline Very high frequency & VHF & 8 & $30-300 \mathrm{MHz}$ & $10 \mathrm{~m}-1 \mathrm{~m}$ \\
\hline Ultra high frequency & UHF & 9 & $\begin{array}{c}300-3000 \\
\mathrm{MHz} \\
\end{array}$ & $1 \mathrm{~m}-100 \mathrm{~mm}$ \\
\hline Super high frequency & SHF & 10 & $3-30 \mathrm{GHz}$ & $\begin{array}{c}100 \mathrm{~mm}-10 \\
\mathrm{~mm}\end{array}$ \\
\hline $\begin{array}{l}\text { Extremely high } \\
\text { frequency }\end{array}$ & EHF & 11 & $30-300 \mathrm{GHz}$ & $10 \mathrm{~mm}-1 \mathrm{~mm}$ \\
\hline & & & $\begin{array}{c}\text { Di atas } 300 \\
\mathrm{GHz}\end{array}$ & $<1 \mathrm{~mm}$ \\
\hline
\end{tabular}

Korona discharge pada SUTET $500 \mathrm{kV}$ akan menyebabkan frekuensi yang memanjang dari $3 \mathrm{KHz}$ sampai dengan $3 \mathrm{GHz}$ jadi terdapat kemungkinan akan terjadi radio interference pada daerah Very Low Frequency (VLF) sampai dengan daerah Ultra High Frequency (UHF).

\section{HASIL DAN PEMBAHASAN}

Studi kasus yang dilakukan pada perhitungan radio interference ini dilakukan pada transmisi SUTET $500 \mathrm{kV}$ Bekasi tepatnya pada tower A56-A57, A57-D58, D58-D59 dan D59-D60, studi kasus akan lebih dikonsentrasikan pada tower A57-D58 karena pada gawang tower ini mempunyai andongan yang paling rendah. Pemilihan pengambilan level RI pada ke empat gawang tower tersebut karena keempat tower tersebut mempunyai jarak andongan terhadap tanah yang paling rendah. Keempat tower teersebut mempunyai jarak andongan ketanah yang berbeda-beda, A56-A57 = 23meter dari tanah, A57-D58 = 20meter dari tanah, D58-D59 = 21meter dari tanah dan D59-D60 = 22 meter dari tanah. Pada A56-A57 terdapat sawah dan jalan raya di bawah salurannya, pada A57D58 dibawah salurannya terdapat tanah lapang sehingga mempunyai andongan yang paling rendah dari yang lainnya, pada D58-D59 dibawah salurannya terdapat sawah, kolam dan beberapa perumahan warga dan D59-D60 terdapat beberapa perumahan warga dibawah salurannya.

Besarnya nilai dari radio interference pada saluran ganda, jenis konduktor yang diamati ialah konduktor ACSR type DOBE dengan luas penampang tiap subkonduktor ialah $327,9 \mathrm{~mm}^{2}$. Prediksi perhitungan radio interference sesuai dengan IEEE radio noise design guide yaitu $30 \mathrm{~m}$ dari fasa terluar ruang bebas SUTET $500 \mathrm{kV}$ yaitu $37,3 \mathrm{~m}$ untuk saluran ganda. Frekuensi dari alat indikator gangguan yang digunakan ialah pada frekuensi radio AM yaitu $0,5 \mathrm{MHz}$. 
Tabel 2. Tabel Perhitungan Radio Interference

\begin{tabular}{|c|c|c|c|c|}
\hline Gawang & $\begin{array}{c}\mathbf{H} \\
\text { (Meter) }\end{array}$ & $\begin{array}{c}\mathbf{N} \\
\text { (Jumlah } \\
\text { Subkonduktor) }\end{array}$ & $\begin{array}{c}\text { RI } \\
(\mathbf{d B})\end{array}$ & Keterangan \\
\hline \multirow{4}{*}{ A57 - D58 } & \multirow{4}{*}{20} & 1 & 102,16 & Asumsi \\
\hline & & 2 & 62,65 & Asumsi \\
\hline & & 4 & 30,3 & Studi Kasus \\
\hline & & 6 & 16,67 & Asumsi \\
\hline \multirow{4}{*}{ D58 - D59 } & \multirow{4}{*}{21} & 1 & 101,85 & Asumsi \\
\hline & & 2 & 62.34 & Asumsi \\
\hline & & 4 & 30,04 & Studi Kasus \\
\hline & & 6 & 16,42 & Asumsi \\
\hline \multirow{4}{*}{ D59 - D60 } & \multirow{4}{*}{22} & 1 & 101,56 & Asumsi \\
\hline & & 2 & 62,05 & Asumsi \\
\hline & & 4 & 29,75 & Studi Kasus \\
\hline & & 6 & 16,18 & Asumsi \\
\hline \multirow{4}{*}{ A56-A57 } & \multirow{4}{*}{23} & 1 & 101,27 & Asumsi \\
\hline & & 2 & 61,79 & Asumsi \\
\hline & & 4 & 29,52 & Studi Kasus \\
\hline & & 6 & 15,95 & Asumsi \\
\hline
\end{tabular}

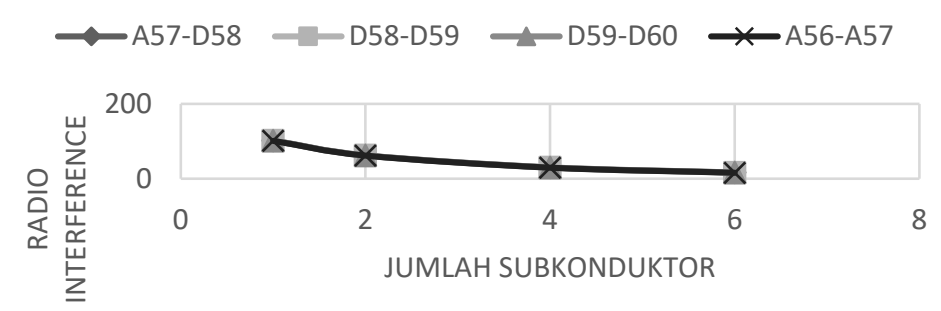

Gambar 4. Grafik Hubungan Antara Jumlah Subkonduktor Dengan Besarnya Radio Interference Pada Masing-Masing Gawang.

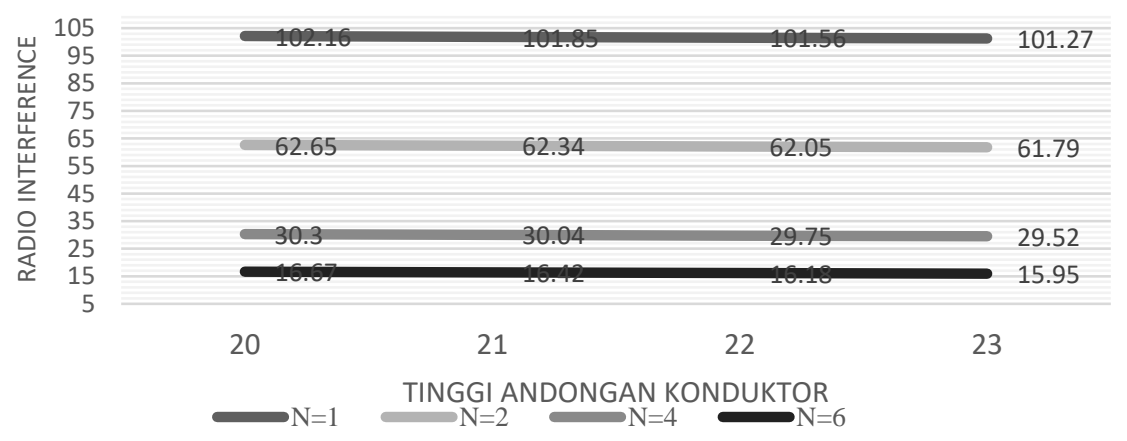

Gambar 5. Grafik Hubungan Antara Tinggi Andongan Terhadap Tanah Dengan Besarnya Radio Interference Pada Masing-Masing Variasi Subkonduktor. 
Semakin tinggi jarak andongan terhadap tanah maka akan semakin kecil nilai dari radio interference dan semakin pendek jarak andongan terhadap tanah maka akan semakin besar nilai dari radio interference.

Pengaruh rugi-rugi daya korona dengan besarnya nilai dari radio interference pada SUTET $500 \mathrm{kV}$ Bekasi dapat dilihat pada tabel berikut.

Tabel 3. Tabel Perhitungan Rugi-Rugi Daya Korona pada Keadaan Cerah dan Level RI pada Keadaan Cerah

\begin{tabular}{|c|c|c|c|c|}
\hline Gawang & $\mathbf{H}$ & $\begin{array}{l}\text { RI cuaca cerah } \\
\text { (dB) }\end{array}$ & $\begin{array}{c}\text { Rugi-rugi daya } \\
\text { korona } \\
(\mathrm{kW} / \mathrm{km} / 2 \times 3 \text { fasa) }\end{array}$ & Keterangan \\
\hline \multirow{4}{*}{$\begin{array}{l}\text { A57- } \\
\text { D58 }\end{array}$} & \multirow{4}{*}{20} & 119,16 & \multirow{4}{*}{8,51} & Asumsi \\
\hline & & 79,65 & & Asumsi \\
\hline & & 47,3 & & Studi Kasus \\
\hline & & 33,67 & & Asumsi \\
\hline \multirow{4}{*}{$\begin{array}{l}\text { D58- } \\
\text { D59 }\end{array}$} & \multirow{4}{*}{21} & 118,85 & \multirow{4}{*}{8,31} & Asumsi \\
\hline & & 79,34 & & Asumsi \\
\hline & & 47,04 & & Studi Kasus \\
\hline & & 33,42 & & Asumsi \\
\hline \multirow{4}{*}{$\begin{array}{l}\text { D59- } \\
\text { D60 }\end{array}$} & \multirow{4}{*}{22} & 118,56 & \multirow{4}{*}{8,11} & Asumsi \\
\hline & & 79,05 & & Asumsi \\
\hline & & 46,75 & & Studi Kasus \\
\hline & & 33,18 & & Asumsi \\
\hline \multirow{4}{*}{$\begin{array}{l}\text { A56- } \\
\text { A57 }\end{array}$} & \multirow{4}{*}{23} & 118,27 & \multirow{4}{*}{7,94} & Asumsi \\
\hline & & 78,79 & & Asumsi \\
\hline & & 45,52 & & Studi Kasus \\
\hline & & 32,95 & & Asumsi \\
\hline
\end{tabular}

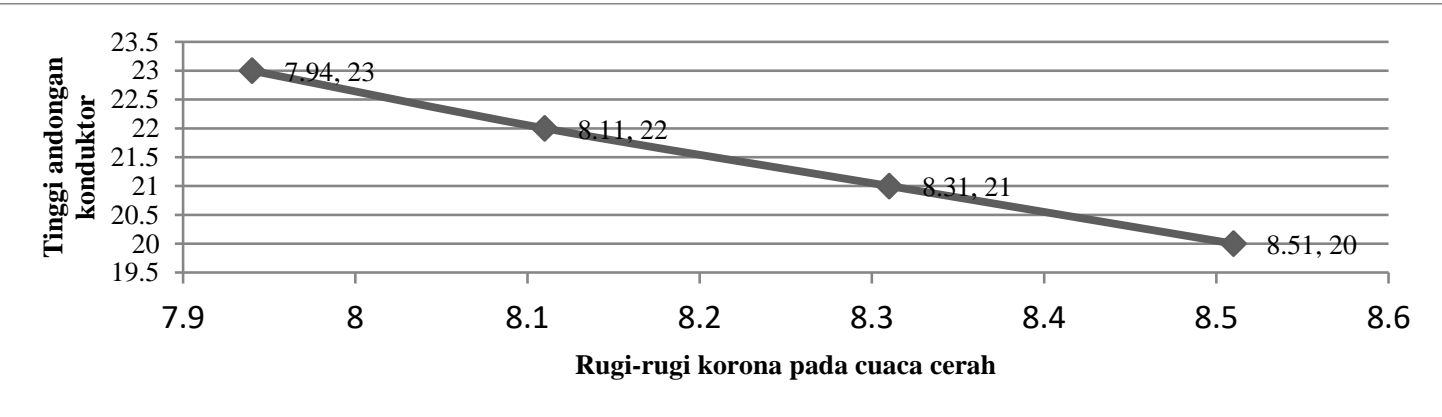

Gambar 6. Grafik Hubungan Antara Tinggi Andongan Konduktor Terhadap Rugi-Rugi Korona pada Tiap Gawang.

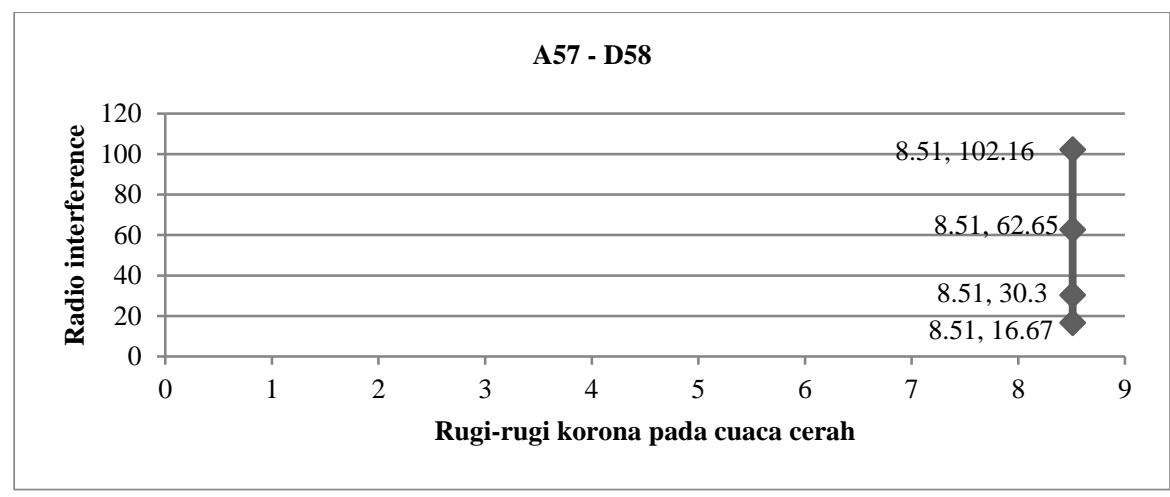

(a) 


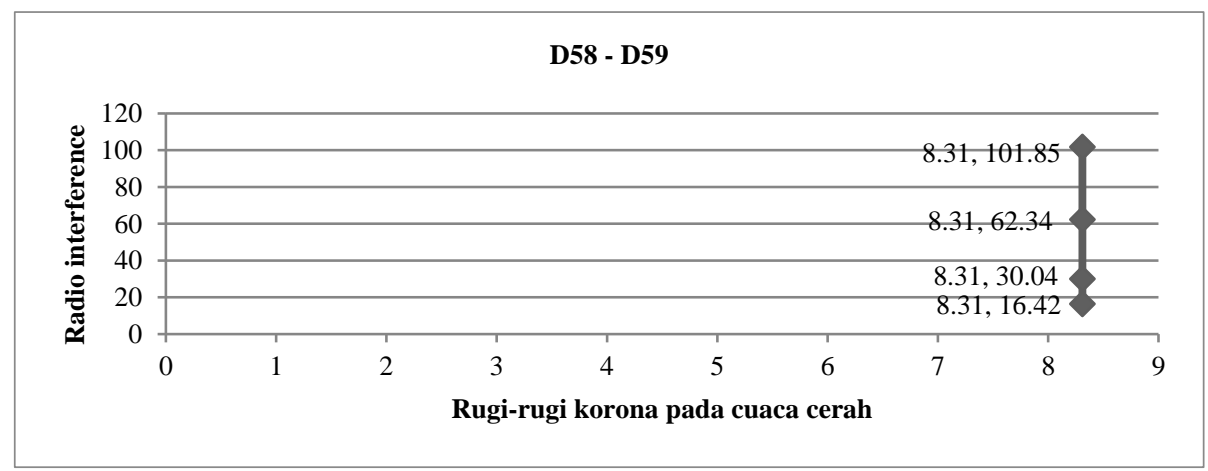

(b)

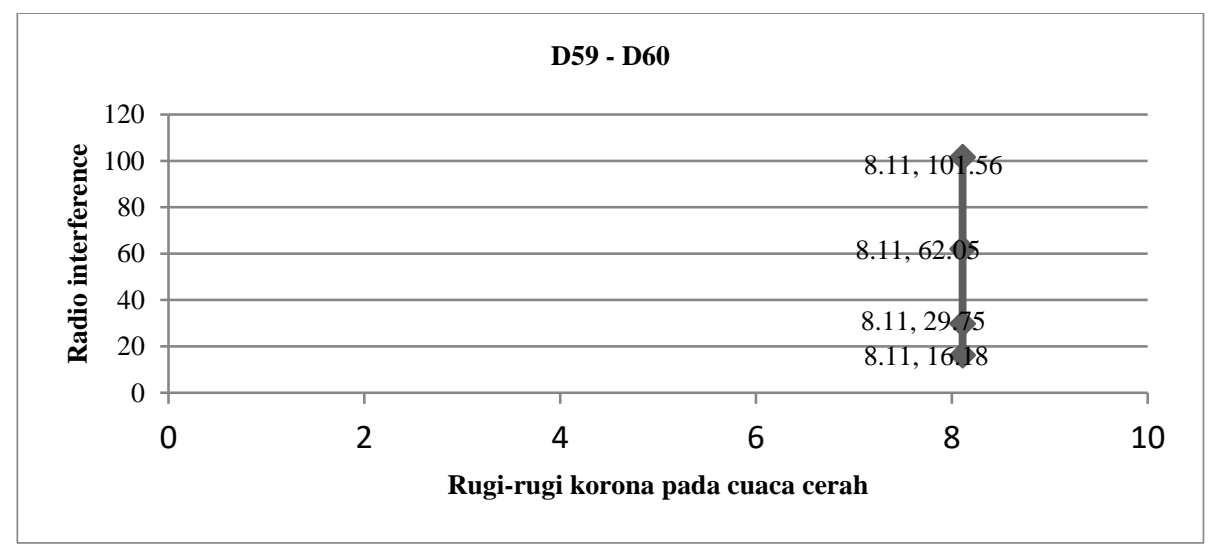

(c)

Gambar 7. Grafik Hubungan Antara Rugi-Rugi Korona Pada Cuaca Cerah Dengan Radio Interference pada Tiap Gawang. (a) pada Gawang A57-D58; (b) pada Gawang D58-D59; (c) pada Gawang D59-D60; (d) pada Gawang A56-A57.

Ketinggian dari konduktor terhadap tanah mempengaruhi besarnya nilai rugi-rugi korona pada cuaca cerah. Semakin tinggi jaraknya terhadap tanah maka akan semakin kecil rugi-rugi korona nya.

Tabel 4. Tabel Perhitungan Rugi-Rugi Daya Korona pada Keadaan Hujan dan Level RI pada Keadaan Hujan

\begin{tabular}{|c|c|c|c|c|c|c|c|}
\hline \multirow{3}{*}{ Gawang } & \multirow{3}{*}{$\mathbf{N}$} & \multirow{3}{*}{$\begin{array}{c}\text { RI cuaca } \\
\text { cerah } \\
(\text { dB })\end{array}$} & \multirow{3}{*}{$\begin{array}{c}\text { RI cuaca } \\
\text { hujan } \\
\text { (dB) }\end{array}$} & \multicolumn{3}{|c|}{$\begin{array}{c}\text { Rugi-rugi daya korona } \\
(\mathrm{kW} / \mathrm{km} / 2 \times 3 \text { fasa })\end{array}$} & \multirow{3}{*}{ Keterangan } \\
\hline & & & & & & & \\
\hline & & & & Pers (7) & Pers (8) & hujan & \\
\hline \multirow{4}{*}{ A57-D58 } & 1 & 102,16 & 119,16 & \multirow{4}{*}{8,51} & \multirow{12}{*}{10} & 305,95 & Asumsi \\
\hline & 2 & 62,65 & 79,65 & & & 102,54 & Asumsi \\
\hline & 4 & 30,3 & 47,3 & & & 25,78 & Studi Kasus \\
\hline & 6 & 16,67 & 33,67 & & & 13,02 & Asumsi \\
\hline \multirow{4}{*}{ D58-D59 } & 1 & 101,85 & 118,85 & \multirow{4}{*}{8,31} & & 312,03 & Asumsi \\
\hline & 2 & 62.34 & 79,34 & & & 101,34 & Asumsi \\
\hline & 4 & 30,04 & 47,04 & & & 25,51 & Studi Kasus \\
\hline & 6 & 16,42 & 33,42 & & & 12,88 & Asumsi \\
\hline \multirow{4}{*}{ D59-D60 } & 1 & 101,56 & 118,56 & \multirow{4}{*}{8,11} & & 301,1 & Asumsi \\
\hline & 2 & 62,05 & 79,05 & & & 100,28 & Asumsi \\
\hline & 4 & 29,75 & 46,75 & & & 25,21 & Studi Kasus \\
\hline & 6 & 16,18 & 33,18 & & & 12,79 & Asumsi \\
\hline
\end{tabular}


Energi dan Kelistrikan: Jurnal Ilmiah

Vol. 11, No. 2, Juli - Desember 2019, P-ISSN 1979-0783, E-ISSN 2655-5042 https://doi.org/10.33322/energi.v11i2.842

\begin{tabular}{|c|c|c|c|c|c|c|}
\hline \multirow{4}{*}{ A56-A57 } & 1 & 101,27 & 118,27 & \multirow{4}{*}{7,94} & 299,12 & Asumsi \\
\hline & 2 & 61,79 & 78,79 & & 99,5 & Asumsi \\
\hline & 4 & 29,52 & 45,52 & & 25,03 & Studi Kasus \\
\hline & 6 & 15,95 & 32,95 & & 12,71 & Asumsi \\
\hline
\end{tabular}

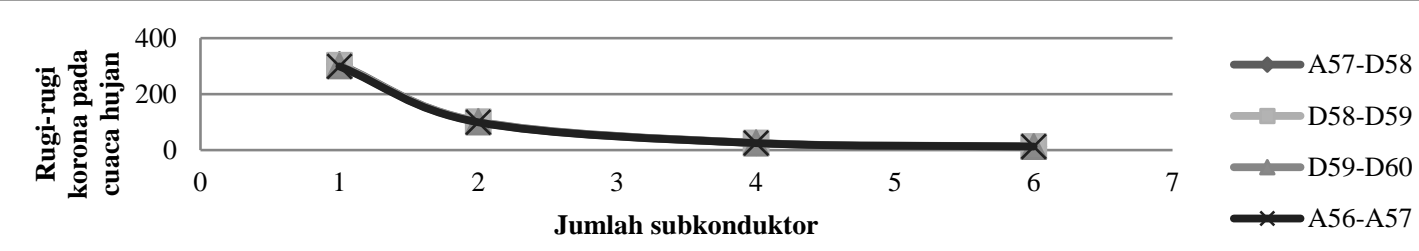

Gambar 8. Grafik Hubungan Antara Jumlah Subkonduktor Yang Digunakan Pada Tiap Gawang Dengan Rugi-Rugi Korona Pada Cuaca Hujan

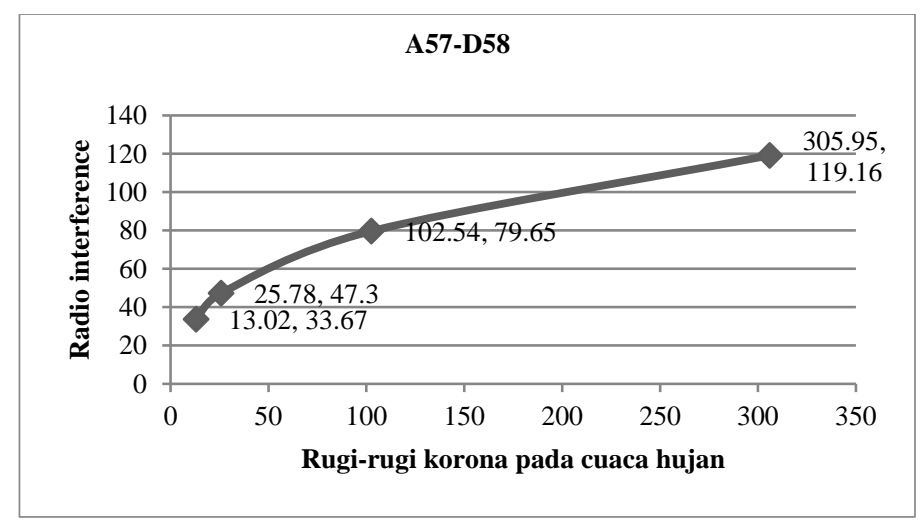

(a)

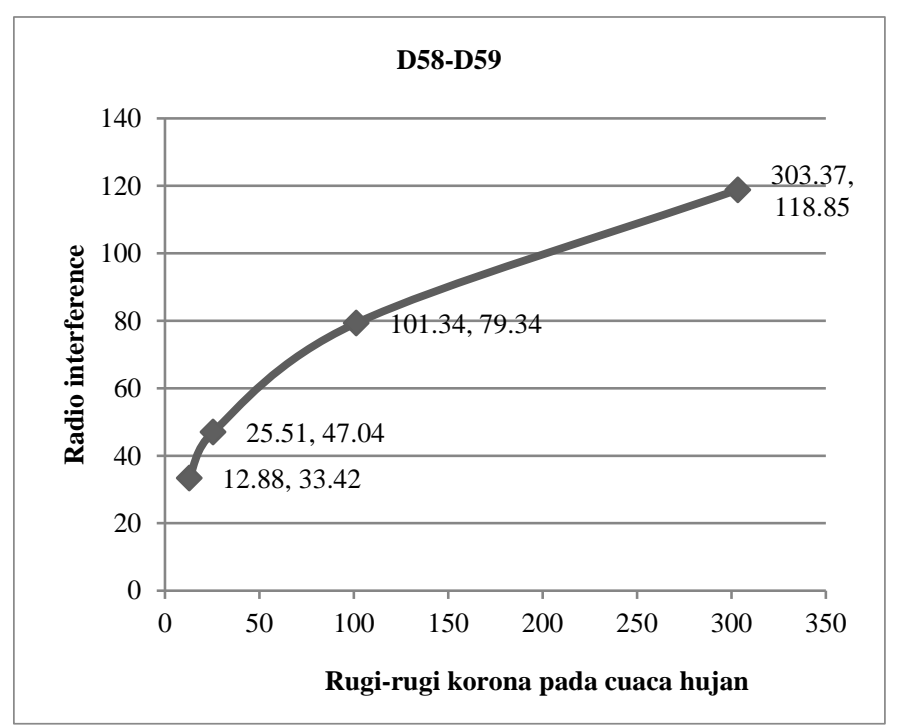

(b) 


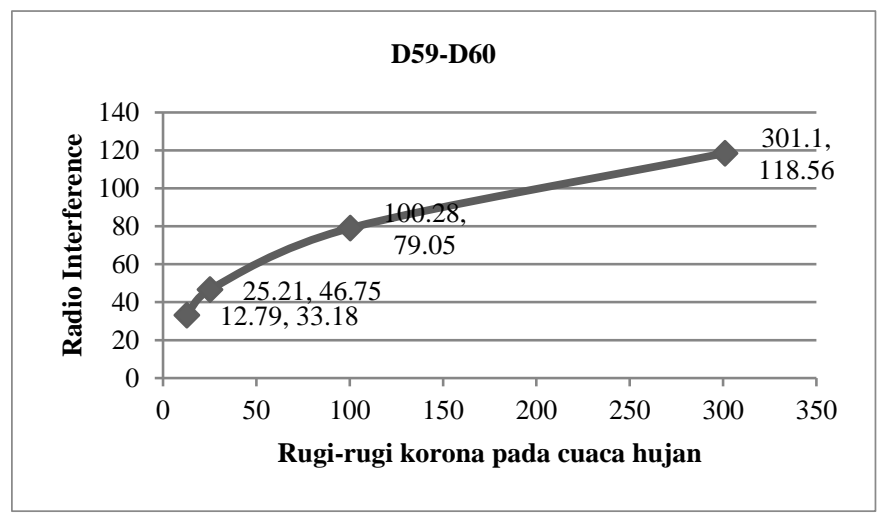

(c)

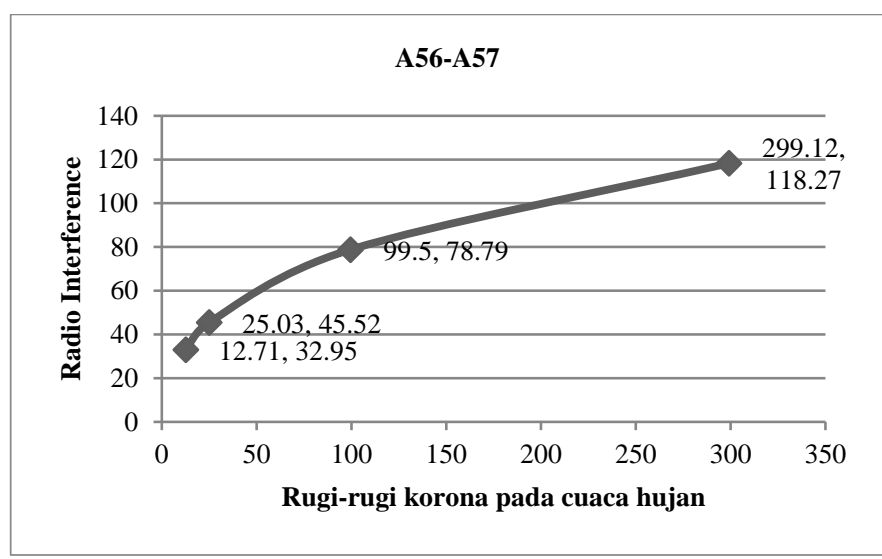

(d)

Gambar 9. Grafik Hubungan Antara Rugi-Rugi Korona pada Cuaca Hujan Dengan Radio Interference pada Tiap Gawang. (a) pada Gawang A57-D58 ; (b) pada Gawang D58-D59 ; (c) pada Gawang D59-D60 ; (d) pada Gawang A56-A57

\section{KESIMPULAN DAN SARAN}

Pada gawang A57-D58, D58-D59, D59-D60 dan A56-A57 mempunyai jarak andongan yang bervariasi antara 20,21, 22 dan 23 meter, hal ini mempengaruhi besarnya radio interference yang terjadi. Pada studi kasus ini gawang A57-D58 ialah gawang yang mempunyai nilai radio interference yang terbesar pada tiap variasi subkonduktor yang digunakan dibanding gawang lainnya. Pada gawang A57-D58, D58-D59, D59-D60 dan A56-A57 untuk cuaca cerah gawang A57-D58 mempunyai rugi-rugi korona yang paling besar diantara gawang lainnya. Hal ini disebabkan karena gawang A57-D58 mempunya jarak andongan terendah dibanding gawang yg lain yaitu 20 meter. Pada gawang A57-D58, D58-D59, D59-D60 dan A56-A57 untuk cuaca hujan gawang A57-D58 mempunyai rugi-rugi korona yang paling besar pada tiap variasi subkonduktor yang digunakan dibandingkan dengan gawang lainnya.

Penambahan jumlah subkonduktor dinilai lebih efektif untuk mengurangi rugi-rugi korona maupun radio interference pada tiap gawang dibandingkan peninggian jarak konduktor terhadap tanah. Dapat disimpulkan bahwa dampak korona pada SUTET $500 \mathrm{kV}$ saluran ganda terhadap radio interference di daerah Jabodetabek masih dalam ambang batas wajar karena masih dibawah standard IEEE yaitu $40 \mathrm{~dB}$. 


\section{DAFTAR PUSTAKA}

[1] Arismunandar, A. dan Kuwahara, S. (1982). Buku Pegangan Teknik Tenaga Listrik Jilid II:Saluran Transmisi, cetakan kelima. Jakarta. Pradnya Paramita.

[2] Arismunandar, A. (1984). Teknik Tegangan Tinggi, cetakan kelima. Jakarta.Pradnya Paramita.

[3] Begamudre, R.D. (1987). Extra High Voltage A.C.Transmission Engineering. New Delhi.Wiley Eastern Limited.

[4] Hutauruk, T. S (1996) Transmisi Daya Listrik, cetakan keempat. Jakarta.Erlangga.

[5] IEEE Radio Noise Subcommittee Report. (1971). "Radio Noise Design Guide For HighVoltage Transmision Lines". Working Group No.3, IEEE Trans. Power Apparatus And System, vol. PAS-90, no. 2, p. 833-842, March/April. 